
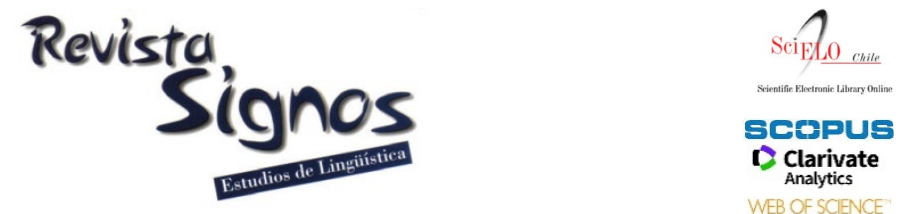

WEB OF SCIENCE

\title{
Hispanic linguistics as a source of community connections for heritage language learners of Spanish*
}

\section{Lingüistica hispánica como fuente de conexión comunitaria para aprendices de español como lengua de berencia}

Angela George

UNIVERSITY OF CALGARY

CANADA

angela.george@ucalgary.ca

\author{
Meghann M. Peace \\ ST. MARY'S UNIVERSITY \\ UNITED STATES \\ mpeace@stmarytx.edu
}

Recibido: 18-III-2018 / Aceptado: 15-X-2018

DOI: $10.4067 /$ S0718-09342019000300975

\begin{abstract}
The teaching of Spanish as a heritage language should attempt to integrate students' background and community into the classroom. Previous studies have found that research in their own community allows learners to embrace their heritage language with pride (Correa, 2011), understand the role that it plays in society (Martínez, 2003; Leeman, 2005), and build stronger community bonds (Leeman, Rabin \& RománMendoza, 2011). This study examines two contexts of university-level Spanish heritage language education. One is San Antonio, Texas, United States, a city with a vibrant Mexican community. The other context is Calgary, Alberta, Canada, a city in which Latin Americans constitute a clear minority. The courses in both contexts were linguistics classes that focused on Spanish as a heritage language. In these courses, the students used journal entries and questionnaires to consider questions about heritage Spanish, language use, attitudes, and the future of the communities' varieties. Their final projects consisted of community-based research, in which they interviewed and collected linguistic data from local Spanish-speakers. Their comments and projects reveal their developing understanding of issues of language use, their recognition of sociolinguistic and attitudinal realities, and a stronger commitment to maintaining Spanish in both the private and the public spheres. These results suggest that, even in communities with minimal Hispanic representation and in courses without an official focus on community engagement, students can still develop a critical understanding of the local variety and the social, cultural, and political factors that contribute to the ways in which it is used.
\end{abstract}

Key Words: Spanish in the United States, high impact classroom practices, language in society, Spanish for academic purposes. 


\section{Resumen}

La enseñanza de español como lengua de herencia debe integrar en el aula las experiencias y la comunidad de sus estudiantes. Algunos trabajos anteriores sugieren que las investigaciones que llevan a cabo los estudiantes en su propia comunidad les permitan ver con orgullo su variedad (Correa, 2011), entender mejor el rol que juega en la sociedad (Martínez, 2003; Leeman, 2005), y desarrollar lazos fuertes en la comunidad (Leeman, Rabin \& Ramón-Mendoza, 2011). El presente estudio examina dos contextos de cursos universitarios diseñados para hablantes de herencia del español. El primero es San Antonio, Texas, Estados Unidos, una ciudad con una comunidad mexicana fuerte. El segundo es Calgary, Alberta, Canadá, una ciudad en la que constituye una minoría la población latinoamericana. Los cursos que se dieron en ambos contextos fueron clases de lingüística que se enfocaron en el español como lengua de herencia. En ellos, los estudiantes consideraron el español como lengua de herencia, el uso de la lengua, las actitudes y el futuro de las variedades en la comunidad. El proyecto final consistió en investigaciones hechas en la comunidad, en las que se les entrevistó a hispanohablantes locales. Los comentarios y proyectos de los estudiantes muestran un entendimiento creciente de las maneras en que se usa la lengua, el reconocimiento de realidades sociolingüísticas y actitudinales, y un fuerte compromiso a mantener el español las esferas tanto privadas como públicas.

Palabras Clave: Español de Estados Unidos, prácticas de alto impacto en el aula, lengua en la sociedad, español con fines académicos.

\section{INTRODUCTION}

A goal of language learning is for learners "to appropriately and effectively engage in global communities both during and after their formal language instruction" in support of ACTFL's Global Engagement Initiative (ACTFL, 2017). One way in which this has been accomplished is through courses that contain a service-learning component. In such courses, students participate in an activity that attempts to address specific community needs; they gain academic credit, gain in their understanding of the discipline, and develop a sense of civic responsibility (Bringle \& Hatcher, 1996). Service-learning has been shown to be beneficial to heritage language learners (HLL) of Spanish, allowing them to serve their communities, increase their sociolinguistic competence, and prepare for future work in multilingual settings (e.g., Jorge, 2006; Leeman et al., 2011; Martínez \& Schwartz, 2012; Thompson, 2012; Lowther Pereira, 2015; Pascual y Cabo, Prada \& Lowther Pereira, 2017).

However, due to curricular, financial, and logistical realities, not all heritage Spanish courses are able to include a service-learning component. Little research has been conducted on the benefits and community connections that Hispanic linguistics courses specifically can bring to students, even in areas that lack a significant Hispanic population.

The current study examines the benefits that community engagement can provide HLLs who are enrolled in upper-level Spanish linguistics courses. Two different contexts are presented, one city in which the Mexican-American population is the 
majority, and one in which Latin Americans are a clear minority. The students presented their understanding of the sociolinguistic realities of the local varieties of Spanish, as well as their attitudes toward it, by means of journal entries and questionnaires. They further explored specific issues of community language use through research projects that involved speakers of the local variety. Their comments and projects were examined for evidence of any critical insights that they might have gained into the social, cultural, and political realities of language use, linguistic attitudes, and the future of United States Spanish.

The remainder of the article is organized in the following manner. Section 1 presents previous work conducted on heritage language learning and service-learning. Section 2.1 describes the first context (San Antonio) and provides the results from the students. Section 2.2 does the same for the second context (Calgary). San Antonio and Calgary are compared in section 3 , and suggestions for future work are also provided.

\section{Background}

This section addresses several topics, i.e., HLLs, service-learning, and the use of Spanish in community contexts. Various approaches to Spanish classes for HLLs are explained, the effects of service-learning on HLLs are described, and the benefits of including a community component in Spanish linguistics courses are discussed.

\subsection{Heritage language learners and their community}

HLLs are students who are:

"Raised in a home where a non-English language is spoken, who speak or merely understand the heritage language, and who are to some degree bilingual in English and the heritage language." (Valdés, 2000: 1)

HLLs tend to receive their formal education and literacy training in English, having learned the heritage language (HL) (in this case, Spanish) in naturalistic settings, such as with their family, in their neighborhood, or in their community (e.g., Correa, 2011). As a result of having learned Spanish in informal settings, HLLs typically exhibit highly developed oral proficiency but have less experience with literary skills. Their oral abilities may exhibit stigmatized features, their vocabulary tends to be limited to the home and community, and borrowings from English are likely (e.g., Leeman, 2005; Kagan \& Dillon, 2008; Correa, 2011).

Several studies have examined HLLs' awareness of and attitudes toward their own variety and varieties spoken in other Spanish-speaking regions. European Spanish tends to be privileged over American varieties (e.g., Leeman, 2012), and, within the Americas, the norma culta of Latin American capitals is considered superior to the Spanish spoken by Hispanics in English-speaking regions (e.g., Bernal, Munévar \& Barajas, 2014; Morett, 2014). Moreover, the presence of English in heritage Spanish is 
frequently disparaged. Leeman (2012) references the pressure felt by Hispanics in English-speaking regions; their language mixing is considered to contain too much Spanish for monolingual English speakers and too much English for monolingual Spanish speakers.

Such pressure comes not only from outsiders -Anglos and Hispanics from Spanish-speaking countries- but also from HLLs themselves. Kroskrity (2004) points out that speakers are not always consciously aware of the ideologies to which they subscribe, and Leeman (2012) finds that speakers of contact varieties of Spanish consider their own speech inadequate, preferring, rather, a more 'pure' Spanish. Tse (1998) proposed a model describing ethnic identity development and the process through with ethnic minorities incorporate diverse cultures into their personal identity. In an early stage of the model, these groups prefer to identify with the dominant culture and have ambivalent or negative feelings about their own heritage. If they are able to proceed to subsequent stages, they may embrace their heritage and accept their minority identity, but not all people are able to do this.

\subsection{Spanish classes for heritage language learners}

Given the insecurity that HLLs may feel and the discrimination and social pressure that they may experience (e.g., Harklau, 2009), the classroom can be a powerful place to address these issues. This may be particularly true if the learners are able to access the Spanish-speaking community and work directly with its members.

Leeman (2005) presents two models of HLL instruction. The normative approach seeks to achieve Valdés' (1997) goal of promoting Spanish maintenance. Students follow an additive model, acquiring the prestige variety of Spanish, while at the same time maintaining their own nonprestige dialect. They are taught that all varieties are legitimate, but that some are more appropriate than others in certain contexts. However, such an approach implies that all varieties are equally legitimate, which the students' own experiences may contradict.

The second model is a critical approach in which students develop an awareness of the linguistic, social, and political factors involved in both their own variety and prestige ones. Not only do students improve their linguistic knowledge, they also gain understanding of the sociopolitical forces involved in language use and policy by investigating topics of interest considered authentic and critical. Through work in their own communities, they actively learn the social functions that dialects can serve. This shows them that their own variety is valid and worthy of investigation (Martínez, 2003; Leeman, 2005; Correa, 2011; Martínez \& Schwartz, 2012). 


\subsubsection{Service-learning by heritage language learners}

Several studies have examined HLL involvement in Spanish-speaking communities through various types of service-learning projects. Research has defined such projects as follows:

"A credit-bearing educational experience in which students participate in an organized service activity that meets identified community needs and reflects on the service activity in such a way as to gain further understanding of the course content, a broader appreciation of the discipline, and an enhanced sense of civic responsibility." (Bringle \& Hatcher, 1996: 222)

In addition to the list of benefits that such community involvement brings students, the following studies suggest that it also provides them with a greater knowledge of their own HL, the role that it serves in its community, and the greater sociocultural context in which the community and the HL exist.

Leeman et al. (2011) examined an after-school literacy program for HLL elementary students, led by university-aged HLL students. The university students were able to take on identities as expert speakers, promote positive social change in helping to maintain the HL, and build community and intergenerational bonds with the elementary students and their parents.

Martínez and Schwartz (2012) presented the results of a semester-long internship in a community health clinic. Pedagogically, the course followed the critical approach described above. The specifics of the internship were determined not only by the faculty but also by community-based stakeholders, such as clinic staff. As a result of the internship, the HLLs expressed a deeper commitment to maintain their Spanish, demonstrated an expanded bilingual range, and showed a greater appreciation of the different purposes that the local variety of Spanish serves within the community.

Pascual y Cabo et al. (2017) measured linguistic attitudes as a result of a servicelearning component in an intermediate conversation course for bilingual speakers. The service-learning component consisted of facilitating five after-school lessons in elementary schools designed to teach the children Spanish. While all HLLs in the study possessed initially positive attitudes, HLLs who completed the service-learning component reported a significant increase in the use of Spanish outside the home and greater linguistic confidence.

Similarly, in addition to increased linguistic confidence and positive attitudes, Lowther Pereira (2015) found increased sociolinguistic awareness in terms of knowledge of different varieties of Spanish after HLLs participated in service-learning as part of a course for advanced HLLs. Likewise, Jorge (2006: 118) found that HLLs who did not regularly speak Spanish developed a "cultural identity, a connection with 
a sociolinguistic structure" through a course that involved connecting with local Spanish-speaking families.

However, no studies have focused on how upper-level linguistics courses can make connections to the Spanish-speaking community and in turn provide the sociolinguistic competence needed for students in their chosen professions. The next section describes this issue in more detail.

\subsection{Linguistics research and community learning}

Martínez and Schwartz (2012) argue that university HL programs must connect with HL communities, for the benefit of both the learners and the communities. However, community engagement is not always possible, due to curricular, financial, or logistical limitations. Despite these limitations, classroom-based courses can help HLLs grow in knowledge of their own variety and gain sociolinguistic competence. Lee, Curtis and Curran (2018) provide an overview of the advances in communitybased service-learning over the past 20 years, discussing both implementation of such programs and pedagogical benefits, and noting the need to "take stock of the leadership and innovative practices already in place in our field and beyond" (Lee et al., 2018: 179). One such practice could be utilizing research projects in linguistics courses to connect to the community.

Upper-division Spanish linguistics courses can provide a locus for student engagement in a multicultural world. Villa (2004) presents one such example at New Mexico State University, a Hispanic-Serving Institution in a majority Hispanic city. Approximately $90 \%$ of the students enrolled in Spanish linguistics classes at New Mexico State are HLLs, who come with the idea that their variety is 'broken' and not valued in society. Through pedagogy that considers learners active participants in the creation of knowledge and, crucially, supports and values their dialect, linguistics courses can help students understand how language is used in society. Villa (2004) describes the benefits that knowledge gained in such classes brought graduates of the program later during their post-graduate professional careers and volunteer work. However, linguistics classes themselves can be a space for community involvement, in areas that have a vibrant Spanish-speaking community and even in those that do not.

While previous research has shown the benefits of service-learning for HLLs, no investigation has described how HLLs can benefit from in-class linguistics projects that require research conducted in the community. The next section discusses two contexts where this occurred, describing each location, the courses in which the students were enrolled, and the linguistic research that they carried out that allowed them to connect to their communities. 


\section{Teaching-learning contexts}

This section presents student comments ${ }^{1}$ taken from in-class journals and final research projects that addressed the issue of community language use. The students were HLLs enrolled in Hispanic linguistics classes in San Antonio, Texas, United States, a city that is majority Mexican and in which approximately one-third of the population speaks Spanish, and Calgary, Alberta, Canada, a city in which only $2 \%$ of the population speaks Spanish.

\subsection{San Antonio, Texas, United States}

San Antonio ranks 9th in U.S. metropolitan areas in terms of Hispanic population. Approximately $56 \%$ of the total population is Hispanic. Of these, almost $90 \%$ are of Mexican descent and 60\% report speaking Spanish at home (Pew Research Center, 2016; Krogstad \& Lopez, 2017). The university is a medium-sized private institution, located several miles from downtown, in a Mexican-American, Spanish-speaking neighborhood. It is a Hispanic-Serving Institution, reflecting the demographics of both the city and the neighborhood.

The results presented here originate from two upper-division Spanish linguistics courses, in which most students were HLLs. In one course, 'Principles and Issues of Second Language Acquisition' (SLA), about half of the instruction was dedicated to SLA, and the other half dealt specifically with HL learning. Of the 17 enrolled students, 16 were Mexican-American HLLs. The second course, 'Spanish in the United States' (SpanUS), dealt with linguistic and social characteristics of U.S. Spanish. Of the 25 enrolled students, 23 were Mexican-American HLLs. Only the HLLs are included in this study.

In both classes, the students completed journal entries throughout the semester. In SLA, their entries responded to questions about the languages they spoke and how others reacted to their speaking Spanish. In SpanUS, the questions asked how the students learned Spanish, the factors that contributed to this, their attitudes toward language mixing, and their opinions about the future of Spanish.

Students in both classes were assessed on a final project consisting of a linguistic investigation. They chose an issue relating to language learning (in SLA) and U.S. Spanish (in SpanUS). They researched previous work on the issue, designed their own study, and recruited local Spanish-speaking participants from whom they collected original linguistic data. Their work was presented to the class in video format, and a written paper was turned in to the professor. 


\subsubsection{Language acquisition and use within the community}

Twenty-one ${ }^{2}$ students stated that they had learned Spanish primarily at home from their family. The remaining three students lived in Mexico during their childhood and learned Spanish there. Two of these students said they spoke Spanish better than English because of their childhood in Mexico. The third student who had lived in Mexico believed that her English had outpaced her Spanish after having moved to the United States. The others either believed that they spoke English better, or that they were equally competent in both languages.

In (1a) and (1b), students indicated the importance that a community of Spanish speakers has for language maintenance; if they lose their community, their language suffers.

(1) a. "Aquí en San Antonio [vs. en El Paso], no hay la misma cantidad de gente que habla el español ... La gran mayoría de mis estudios son en inglés, así que mientras que mi vocabulario en inglés ha crecido increíblemente, mi vocabulario en español se ha quedado en el mismo nivel.” (SpanUS)

b. "Mi abuela fue la fuente primaria del input que recibí en español, y fue también la maestra más importante en mi aprendizaje de la lengua. Falleció el año pasado, y como ella era la única con quien hablaba el español, no lo practico ni lo hablo tanto como más antes.” (SpanUS)

In general, their comments demonstrate diglossia; ${ }^{3}$ Spanish was the language of the home and the family, whereas school was an environment largely conducted in English. The students exhibited a certain level of self-confidence in their Spanish abilities, though some were more confident than others. Their abilities tended to correspond with the quantity and quality of opportunities to use Spanish within their families and communities.

As for the students' opinions regarding the future of Spanish in their communities, they were almost entirely positive. Some of the reasons they believed that Spanish would be maintained in San Antonio were the importance of local demographics, businesses marketing to Spanish-speakers, bilingual schools, and Anglo acceptance of and appreciation for Hispanic culture. In (2), they contrast San Antonio with other areas of the United States.

(2) a. 'La idea de 'English Only' no apoya el mantenimiento del español en los Estados Unidos. La idea de que el español está amenazando al inglés es una idea que causará la pérdida del español. Pero en lugares como San Antonio no creo que sea un problema mantener el español.” (SpanUS)

b. "Yo creo que en San Antonio se va a mantener porque hay mucha gente hispana y la actitud sobre el español es positiva. Hay personas que hablan 
español ... En [Illinois] creo que se va a desplazar porque no hay muchos hispanos ... no muchas personas que hablen el español en centros de salud o escuelas." (SpanUS)

The comment in (2a) indicates that Spanish maintenance depends not only on Hispanics and their demographic presence, but on Anglos and their attitudes as well. This is echoed in (3), in which a student expressed pessimism about the future of Spanish in Arizona, her home state.

(3) "Las actitudes lingüísticas son positivas en comunidades hispanas, pero en otras ciudades las actitudes lingüísticas hacia el español es negativo. El español está presente en las comunidades hispanas, pero no en otras ciudades aunque estén solo 20 minutos de lejos." (SpanUS)

Demographic presence, positive ingroup and outgroup attitudes, and the use of Spanish by institutions, families, and society were cited as factors that would likely contribute to the maintenance of Spanish in San Antonio.

Although the students were generally positive about the presence and future of Spanish in their community, they had, at the same time, certain insecurities regarding their particular type of Spanish. The comments in (4) demonstrate their negative attitudes toward language mixing.

(4) a. "El spanglish para mí es muy normal. Pero no me gusta porque no se me hace formal. No me gustaría que mis hijos hablen spanglish porque me hace como que no aprenderían ni el español o inglés correctamente.” (SpanUS)

b. "El espanglish es bueno para las personas que están aprendiendo una lengua que es como el español y el inglés. Pero no se debería de usar en un trabajo profesional." (SpanUS)

c. "Creo que spanglish ayuda a muchas personas a mantener y practicar los dos diferentes idiomas. Sin embargo, en mi opinión no es muy beneficioso porque cuando una persona usa spanglish tiende a perder la habilidad de hablar correctamente uno o los dos idiomas." (SpanUS)

d. "Yo creo que todos hacen errores ... [como que] en español hablamos nuestro lengua nativo como 'Tex-Mex'.” (SLA)

e. "En la frontera ... la mayoría de las personas hablan español e inglés, pero hay ciertas cosas que suenan extrañas para alguien de México. Es una combinación de español y TexMex, lo más cerca que estás de México lo más correcto habla uno español." (SLA) 
While they recognized that 'Spanglish'/'Tex-Mex' can be useful in bilingual communities, they also felt that it is incorrect and to be avoided in professional settings.

\subsubsection{Linguistics projects within the community}

Projects were carried out in SLA (done individually) and SpanUS (done in pairs). The students selected topics relevant to issues in the field and conducted studies meant to explore them, using linguistic data collected from the community. The topics presented here all dealt with language use in the family/community.

The topic of attitudes toward U.S. Spanish appeared in two projects. One pair of students had frequently observed language mixing in San Antonio, and they asked community members for their opinions on it.

(5) "También pudimos ver que, aunque los participantes evitan el uso de spanglish, y no necesariamente ven un valor en la mezcla de inglés y español, reconocen la importancia en poder identificarse con los que nos rodean ... Una de las participantes respondió que para ella el spanglish significa su cultura, la manera de expresarse y carácter." (SpanUS)

One of the students had stated in her journal -in (4b) - that she felt that language mixing ought to be avoided in professional settings. However, in the project, she wrote:

(6) "El spanglish es algo muy real, se encuentra en nuestro alrededor, y en realidad no se puede evitar, especialmente porque es un fenómeno natural ... Debemos descartar cualquier actitud negativa que tenemos sobre el spanglish porque se ha convertido en una manera creativa que comunicarse.” (SpanUS)

The second project also examined attitudes, being inspired by a local art exhibit 'Aqui estamos y no nos vamos' (Mariposa, 2017) and recent negative political discourse directed at U.S. Hispanics. A pair of students interviewed 16 participants, consisting of Spanish speakers and non-Spanish speakers, Hispanics and Anglos. Every Spanishspeaking participant felt positively about the language, whether they spoke it natively or non-natively. Non-Spanish-speaking Hispanics were mixed, and non-Spanishspeaking Anglos exhibited negative opinions of Spanish, which could have been influenced by their views of Spanish speakers. The two students who carried out the project felt that further research would be necessary to fully understand the opinions and experiences of Spanish-speaking Anglos and non-Spanish-speaking Hispanics.

The latter group, non-Spanish-speaking Hispanics, was of interest to two students who investigated why Hispanic parents do not teach Spanish to their children. They knew many families in which the parents spoke Spanish, but the children did not. This had always been a source of confusion for them, as their own parents had taught them 
Spanish. Their investigation helped them to understand why people from families similar to theirs might grow up with far less exposure to Spanish, in (7).

(7) a. "Una gran razón de que los padres no les enseñan a sus hijos el español es porque la sociedad en que vivimos no les permite porque dicen que como estamos en los Estados Unidos solo pueden hablar inglés ... Otra razón porque los hijos no aprenden el español de sus padres es porque no tienen interés en aprenderlo." (SLA)

b. "Hay algunas personas que niegan aprender o hablar el español por la inseguridad o el miedo de que gente se ría de ellos y burlen o los juzguen por hablar una lengua que no sea el inglés ... Siempre hay unos padres que piensan que es mejor para sus hijos que aprendan el inglés en vez del español porque les parece que es más importante el inglés.” (SLA)

They stated learning the following:

(8) a. "Lo mejor que aprendí que me podrá servir en el futuro es que ahora cuando conozca a alguien que tenga padres que hablen español, pero ellos mismos no hablen el español, ya sabré muchas razones porque no lo aprendieron y no los juzgaré." (SLA)

b. "Aprendí unas maneras en que puedo hablar con mis hijos o niños más chicos para ayudarles a aprender una diferente lengua ... que aprendan que no es malo y que no deben de estar avergonzados de hablar otra lengua.” (SLA)

This project helped the students articulate language loss in their society and imagine possible futures.

Other projects that examined Spanish use within families were two that focused on the effect of birth order in linguistic development. One student had personal reasons for conducting the study.

(9) "Yo todavía era capaz de aprender los dos idiomas debido a la forma que mis padres me criaron. Comparado a mi hermana y hermano [menores], ellos fueron criados con menos español." (SLA)

The students researched the different roles that older and younger children play within the family, as well as the type and quantity of input provided by their family, their friends, and society. Society in particular played a role.

(10) "Unas de las actitudes negativas que influyen a la pérdida de la L1 es cuando los hijos entran a la escuela y descubren que su L1 no tiene un valor significativo en su escuela y tienen que aprender a hablar inglés para ser aceptados en la sociedad." (SpanUS) 
They found that this issue is not limited to the family, but is also influenced by the larger community.

Another project examined the use of Spanish in different generations of the family -immigrants vs. their children. The students commented:

(11) "Los entrevistados de primera generación están experimentando la vida en los Estados Unidos, lo que explica su uso del cambio de código, pero la influencia hispana en el suroeste los ayuda a mantener entonces pueden mantener su idioma nativo ... los hispanos de la segunda generación son más asimilados a la sociedad estadounidense." (SpanUS)

Throughout the project, however, they recognized the complex interplay of factors that explained their participants' use of both languages, such as social networks, community demographics, social class, and even the specific topic of conversation. They realized that the question cannot be reduced simply to the speakers' generation, in (12).

(12) "Aprendimos que ambas generaciones navegan tanto en su cultura mexicana como en su cultura americana interdependientemente - cada generación entrevistada está influenciada por ambas culturas.” (SpanUS)

For the final project presented here, two pairs of students in SpanUS explored the linguistic landscape of San Antonio, selecting four distinct neighborhoods and analyzing the language(s) used on signs and announcements therein. The neighborhoods were the West Side (Mexican), the Northwest Side (multiple ethnicities, principally Anglo), Alamo Heights (Anglo and wealthy), and downtown (a tourism and business center).

Even on the West Side, Spanish was limited to signs for health clinics and business offering loans and insurance. Major chains and churches showed little evidence of Spanish. On the Northwest Side and in Alamo Heights, English was the primary language, with the exception of signs on certain law offices and health clinics. There was almost no evidence of Spanish downtown. The students concluded:

(13) "No solamente porque la población es predominantemente hispanohablante signifique que esa será la lengua que se usa más en los establecimientos para atraer más clientela, y en San Antonio, aunque está muy presente el español, la lengua que domina es el inglés." (SpanUS)

The diglossia that the students' journals presented was reflected in the linguistic landscape of San Antonio. Spanish is reserved for the home, whereas English is used in public spaces such as businesses, churches, clinics, and most signs. 
Overall, the students' projects originated in their own lived experiences in Spanishspeaking families and communities, which are in turn embedded in the larger Englishspeaking societies of San Antonio, Texas, and the United States. These projects provided the students with the opportunity to consider their personal issues and communities from a sociolinguistic perspective, engage with them in a substantial way, and expand their understanding to the wider and more complex context of SpanishEnglish contact in the United States.

\subsection{Calgary, Alberta, Canada}

The second teaching-learning context was in Calgary, Canada. According to Statistics Canada (2016), among metropolitan areas in Western Canada, Calgary has the largest Hispanic population, tied with Vancouver. In the city of Calgary, 2.1\% of the population speaks Spanish, and 1.3\% of the population is Hispanic (Statistics Canada, 2018). Across the country, Spanish is the third most widely spoken minority language. ${ }^{4}$ The university in question is a large public research institution, located in the largest metropolitan area in the province of Alberta.

The results presented here stem from an upper-level course titled 'Identity and Heritage', which addressed issues of identity and multilingualism, the sociohistorical context of bilingualism in Spanish-speaking regions, the development of Spanish as a HL, and Spanish as it is spoken in Canada. Of the 14 students enrolled in the class, eight spoke Spanish at home. With one exception, these eight students had relocated to Canada as children, from Colombia, Mexico, Peru, and Chile. The remaining six students were second language learners of Spanish. All had traveled abroad to various Spanish-speaking locations.

Students read articles and responded to weekly discussion forums in which they engaged with each other on the topic of HLs. Examples of what they discussed include who they considered to be an HLL, their abilities in both Spanish and English, and the future of Spanish in both the United States and Canada. The final project consisted of interviewing a Spanish speaker in Calgary, presenting this interview to the class, and writing an academic paper about the interview. In this paper, the students detailed the linguistic profile of the interviewee, analyzed discourse surrounding identity and bilingualism, and described the language used by the interviewee using concepts learned in class, such as code-switching.

\subsubsection{Language acquisition and use within the community}

Most students noted that they used Spanish at home and among friends, and English at the university and in public. The presence of Spanish in the home and the importance of conserving one's Latin American identity by surrounding oneself with Latinos is emphasized in the following quote: 
(14) "Tengo muchos años viviendo en Canadá, pero no convivo con muchas personas canadienses, todos mis amigos son latinos, y por esa razón se me hace un poco difícil identificarme como canadiense. Siempre prefiero decir que soy de México solamente."

The students who came to Canada as older children considered themselves to be native speakers, not HLLs, as one student stated:

(15) "No me considero un hablante de herencia, me considero un hablante nativo porque crecí en México hasta los 12 años, aprendí bien el español y aun sigue siendo la lengua que domino mejor."

However, this diglossic situation is changing with younger children, both those born in Canada and those who moved to Canada at a young age. One student noticed this in her younger siblings, who prefer to speak English at home even though their parents speak Spanish.

(16) "Yo tengo dos hermanos pequeños que entienden español, pero no quieren aprender a hablarlo, siempre prefieren hablar en inglés."

The role of a multicultural place as a positive influence on multilingualism was a prevalent theme throughout the semester and evidenced in (17a) by a student who described how easy it was to adapt to Canada and in (17b) by a student who noted the contrast between Canada and the United States in this regard.

(17) a. "La cultura ayudó mucho que Canadá es un país multicultural y la gente suele ser muy comprensiva con los inmigrantes."

b. "Vivimos en un país donde no hay discriminación hacia otros idiomas o culturas como en Estados Unidos, sino que al contrario, hablar varias lenguas es visto como algo bueno y abre muchas puertas a oportunidades."

The advantages of being bilingual were discussed by several students, including its academic benefits (18a) and its cultural connections (18b, c).

(18) a. "El ser bilingüe me ha ayudado a memorizar los conceptos con mayor facilidad y ha poder al igual, pertenecer a grupos diferentes de habla."

b. "Uno de los beneficios que me ha traído ser bilingüe, ha sido el poder de conocer más de una cultura."

c. "Tengo muchas costumbres colombianas pero he desarrollado costumbres canadienses que hacen que me identifique de dos nacionalidades."

The students were all very positive about the future of Spanish, stating how to maintain Spanish across generations in (19a), their desire to raise a bilingual child in 
(19b), the future of 'Spanglish' in (19c), and how immigration can prevent language loss in $(19 \mathrm{~d})$.

(19) a. "Algo que pueden hacer los padres para conservar el idioma es escuchar música tradicional del país, visitando amigos y tener eventos culturales, hacer comida tradicional, visitando el país cuando puedan, hablar el idioma, y hablar de las experiencias que tuvieron al estar allá."

b. "Me gustaría que mi hija fuera bilingüe y que hablara los dos idiomas por igual."

c. "Lo que sí pienso es que poco a poco surge un nuevo "idioma" al que le llamamos 'spanglish' que puede llegar a ser un idioma oficial dejando al español a un lado.”

d. "No, el español no podría desaparecer en Canadá, ni en Estados Unidos porque siempre habrá emigrantes hispanos que van a llegar a estos países. En cuanto a la educación muchos valoran el español y lo enseñan en las escuelas."

\subsubsection{Linguistics projects within the community}

The students' final projects consisted of interviews with a member of the local Spanish-speaking community. Students recorded this interview, via video or audio recorder, and transcribed the parts they deemed most important. In the paper, they described their speaker's background, linguistic profile, and any linguistic aspects noted in their speech, such as /s/-aspiration, the use of loanwords, or calques.

Students reflected on what they learned in the interviews about the Spanishspeaking community in Calgary. The responses about the perceived size of the community were conflicted, as seen in (20a) and (20b). The prevalence of English in the Spanish-speaking community was noted in (20c) and (20d).

(20) a. "Aprendí que hay muchos más hispanohablantes de los que pensaba en Alberta y Calgary y que la lengua se va perdiendo conforme hay más generaciones."

b. "Que no es tan grande como se cree y no tiene impacto que sí lleve en otros lugares anglosajones."

c. "Descubrir los calcos de mi participante y ver el conflicto que hay entre su identidad lingüística y cultural ... Pensaba que no habría mucho desapego a la lengua española, pero hay hablantes con más conexión al inglés."

d. "Piensa en inglés en lugar de en español. Esto me sorprendió ya que el español es su lengua materna y es hablante de primera generación." 
As evidenced in the quotations in this section, students in both contexts engaged with their local communities while conducting research projects. The next section contextualizes these quotations more and compares the two contexts.

\section{Discussion}

This paper presents the ways in which Hispanic linguistics classes can be used as a source of community connections for HLLs. Two different contexts are presented one in which the Hispanic population is the majority, and one in which it is a minority. The results from the classes show that, even in the absence of a significant Hispanic population and lack of official curricular focus on community engagement, students can enhance their understanding of the local variety, its maintenance or loss, and the various social, cultural, and political factors that contribute to the ways in which it is used. This knowledge may serve them in their future professional or social interactions with the community.

Despite significant differences in the two cities' demographics, several common themes emerged. In both San Antonio and Calgary, students noticed the presence and influence of English in the Spanish of their families and communities. Their experiences with the two languages suggest diglossia in both cities; English is the language of public activities, whereas Spanish is reserved for the home and family. They reported the presence of language mixing through code-switching, lexical borrowings, and calques. In both cities, their experiences suggest similar trends; younger siblings are less likely to maintain the language than older siblings, and subsequent generations are more likely to switch to English rather than maintain Spanish.

Despite observations of language attrition and loss, students' views regarding the future of Spanish in their communities were relatively positive. They believed that Spanish would continue to exist in San Antonio and Calgary. They discussed positive attitudes toward the language, family and community events, cultural activities, the desire to speak Spanish with their own children, and schools in which Spanish is taught and valued. They maintained this optimism about the future of Spanish while at the same time holding negative views of 'Spanglish' as too informal and not professional enough.

The projects that the students carried out in the community, however, suggested that the future of Spanish might not be as positive as they might imagine. In San Antonio, they encountered personal and social reasons as to why families might choose to not speak Spanish to their children, or why immigrants might use English rather than Spanish. Despite the overwhelming presence of Spanish speakers in the city, they discovered that the majority of public signs are in English, rather than Spanish or a mix of the two languages. In Calgary, they observed the presence of English, even among first generation Hispanics. 
The students' work suggests that language maintenance or loss in a community may depend just as much on social and attitudinal realities as on demographics and immigration. For instance, they were relatively positive about the future of Spanish in San Antonio, using as support for this position the presence of Spanish speakers and the positive attitudes of the city's residents, schools, and businesses toward Mexican culture. In (2b), a student contrasted San Antonio with Illinois, which has a smaller Hispanic presence. ${ }^{5}$ However, it is not only demographics that play a role. The comments in (2a) and (3) suggest that, even in areas with significant Hispanic populations, such as Arizona, prevailing negative attitudes toward Spanish might lead to language loss. This theme is supported by the comments from Calgary, in which students contrasted Canada with the United States. In (17), Canada is presented as a country in which immigrants are treated well, multiculturalism and multilingualism are valued, and the discrimination that occurs in the United States is relatively unknown. Compare these comments to the San Antonio comments in (2a) and (3), which emphasize negative attitudes, particularly in the political sphere, toward Spanish speakers. Spanish may be accepted in San Antonio, but San Antonio is not equivalent to other parts of the United States. Demographic presence is one important factor in maintaining Spanish, but social and cultural acceptance is another, as the students discovered through the exposure to the community that these classes gave them.

The students' work suggests that the future of the language is entirely dependent on the community -families, schools, businesses, and prevailing attitudes among both ingroup and outgroup members. It may not be enough that these students, as future parents, maintain Spanish with their children; they also need to use it in schools, clinics, businesses, advertisements, etc., in the public sphere. These projects helped the students better understand and accept the sociolinguistic reality of their variety of Spanish. The hope is that they will continue to use their language in professional settings in the future, helping to transform their landscape into one in which the language is visible and valuable in both private and public spheres.

\section{CONCLUSIONS}

This paper can act as a springboard for future studies that are either empirical or descriptive in nature and that take into account several aspects not present in the current study. Pre and post surveys can be conducted to determine changes in attitudes, such as in Pascual y Cabo et al. (2017), which could be triangulated with interviews to further elucidate students' attitudes toward bilingualism and to measure sociolinguistic competence. These could then be compared to responses from second language learners.

This paper presents several possibilities for linguistics research, and we are certain there are more that could be explored. For example, the use of linguistics research in 
online communities could provide connections to Spanish-speaking communities at a distance. This might help students who live in areas without many Spanish-speakers increase their sociolinguistic competence.

While the students in San Antonio and Calgary presented their research to their classmates and professor, it could prove beneficial to present to the larger community. Sharing their work in a community-based forum would further disseminate sociolinguistic knowledge and provide additional opportunities for students to reflect on their own learning and connect with others. By making connections beyond their local communities, students may gain awareness of prevailing issues that are similar even in vastly different contexts, as these two settings show.

Such work need not be limited to Hispanic linguistics classes, although certainly the topics and the types of research methodology covered therein make it an appropriate venue. Courses that focus on social research methods, community and civic engagement, language contact, and minority issues, among others, can also benefit from including such types of community-based research in their curricula.

Finally, following students through to their chosen professions could provide evidence for more long-term benefits that undergraduate-level, community-based, sociolinguistics research can offer.

Despite two vastly different contexts, similar themes arose among HLLs in Hispanic linguistics classes. In both San Antonio and Calgary, students exhibited positive attitudes toward Spanish, particularly regarding its maintenance, despite remarkably different demographics in both cities. In contrast, their attitudes toward language mixing were generally negative. They tended to regard it as an incorrect way of speaking and strove to speak a monolingual variety of Spanish.

Research projects in their Spanish linguistics courses helped students consider the larger issues inherent in maintaining/not maintaining Spanish, choosing to use English or Spanish, and the functions of language mixing in the community. Interacting with community members allowed them to engage deeply and substantially with the issues that most interested them, expanding on topics presented in textbooks and articles. The comments from the San Antonio and Calgary HLLs suggest that students in all types of contexts might benefit from community-based research projects by envisioning social contexts beyond their personal experiences, viewing minority languages/varieties as a serious topic of academic inquiry, and gaining critical insights into issues of language use.

\section{REFERENCES}

ACTFL. (2017). ACTFL's Global Engagement Initiative [on line]. Retrieved from: https://www.actfl.org/about-the-american-council-the-teaching-foreignlanguages/actfl-global-engagement-initiative 
Bernal, J., Munévar, A. \& Barajas, C. (2014). Actitudes lingüísticas en Colombia. In A. B. Chiquito \& M. A. Quesada Pacheco (Eds.), Actitudes Lingüisticas de los Hispanohablantes hacia el Idioma Español y Sus Variantes. Bergen Language and Linguistic Studies (BeLLS), 5 [on line]. Retrieved from: http://dx.doi.org/10.15845/bells.v5i0.680

Bringle, R. \& Hatcher, J. (1996). Implementing service-learning in higher education. The Journal of Higher Education, 67(2), 221-239.

Correa, M. (2011). Advocating for critical pedagogical approaches to teaching Spanish as a heritage language: Some considerations. Foreign Language Annals, 44(2), 308-320.

Fasold, R. (1984). The Sociolinguistics of Society. Oxford, UK: Blackwell.

Harklau, L. (2009). Heritage speakers' experiences in new Latino diaspora Spanish classrooms. Critical Inquiry in Language Studies, 6(4), 211-242.

Jorge, E. (2006). Journey home: Connecting Spanish-speaking communities at home and abroad. Hispania, 89, 110-122.

Kagan, O. \& Dillon, K. (2008). Issues in heritage language learning in the United States. In N. Van Deusen-Scholl \& N. H. Hornberger (Eds.), Encyclopedia of Language and Education (2nd ed.) (pp. 143-156). New York, NY: Spring Science $\&$ Business Media.

Krogstad, J. M. \& Lopez, M. H. (2017). Use of Spanish declines among Latinos in major U.S. metros [on line]. Retrieved from: http://www.pewresearch.org/fact$\operatorname{tank} / 2017 / 10 / 31 /$ use-of-spanish-declines-among-latinos-in-major-u-smetros/

Kroskrity, P. (2004). Language ideologies. In A. Duranti (Ed.), A Companion to Linguistic Anthropology (pp. 496-517). Malden, MA: Blackwell.

Lee, C., Curtis J. \& Curran, M. (2018). Shaping the vision for service-learning in language education. Foreign Language Annals, 51, 169-184.

Leeman, J. (2005). Engaging critical pedagogy: Spanish for native speakers. Foreign Language Annals, 38(1), 35-45.

Leeman, J. (2012). Investigating language ideologies in Spanish as a heritage language. In M. A. Fairclough \& S. M. Beaudrie (Eds.), Spanish as a Heritage Language in the United States: The State of the Field (pp. 43-59). Washington, DC: Georgetown University Press. 
Leeman, J., Rabin, L. \& Román-Mendoza, E. (2011). Identity and activism in heritage language education. The Modern Language Journal, 95, 481-495.

Lowther Pereira, K. (2015). Developing critical language awareness via servicelearning for Spanish heritage speakers. Heritage Language Journal, 12, 159-185.

Mariposa, R. (2017). (Curator). Aquí estamos y no nos vamos [on line]. Retrieved from: http://esperanzacenter.org/ event/aqui-estamos-y-no-nos-vamos-exhibitopening/

Martínez, G. A. (2003). Classroom based dialect awareness in heritage language instruction: A critical applied linguistic approach. Heritage Language Journal, 1, 1-14.

Martínez, G. \& Schwartz, A. (2012). Elevating “low” language for high stakes: A case for critical community-based learning in a medical Spanish for heritage learners program. Heritage Language Journal, 9(2), 175-187.

Morett, S. (2014). Actitudes lingüísticas en México. Entre el chovinismo y el malinchismo. In A. B. Chiquito \& M. A. Quesada Pacheco (Eds.), Actitudes Lingüisticas de los Hispanohablantes hacia el Idioma Español y Sus Variantes. Bergen Language and Linguistic Studies (BeLLS), 5 [on line]. Retrieved from: http://dx.doi.org/10.15845/bells.v5i0.688

Pascual y Cabo, D., Prada, J. \& Lowther Pereira, K. (2017). Effects of community service learning on heritage language learners' attitudes towards their language and culture. Foreign Language Annals, 50(1), 71-83.

Pew Research Center. (2016). Hispanic population and origin in select U.S. metropolitan areas, 2014 [on line]. Retrieved http:/ / www.pewhispanic.org/interactives/hispanic-population-in-select-u-smetropolitan-areas/

Statistics Canada. (2016). Census Profile, 2016 Census [on line]. Retrieved from: http://www12.statcan.gc.ca/census-recensement/2016/dp$\mathrm{pd} /$ prof/details/page.cfm?Lang $=\mathrm{E} \& \mathrm{Geo} 1=\mathrm{POPC} \&$ Code $1=0115 \& \mathrm{Geo} 2=\mathrm{P}$ $\mathrm{R} \&$ Code $2=48 \& \mathrm{Data}=$ Count $\&$ SearchText $=$ calgary $\&$ Search Type $=$ Begins $\&$ Sea $\mathrm{rchPR}=01 \& \mathrm{~B} 1=\mathrm{All} \& \mathrm{TABID}=1$

Statistics Canada (2018). Population of census metropolitan areas [on line]. Retrieved from: http://www.statcan.gc.ca/tables-tableaux/sum-som/101/cst01/demo05aeng.htm

Thompson, G. (2012). The Intersection of Service and Learning: Research and Practice in the Second Language Classroom. Charlotte, NC: Information Age Publishing. 
Tse, L. (1998). Ethnic identity formation and its implications for heritage language development. In S. Krashen, L. Tse \& J. McQuillan (Eds.), Heritage Language Development (pp. 15-29). Culver City, CA: Language Education Associates.

Valdés, G. (1997). The teaching of Spanish to bilingual Spanish-speaking students: Outstanding issues and unanswered questions. In M. C. Colombi \& F. X. Alarcón (Eds.), La Enseñanza del Español a Hispanohablantes: Praxis y Teoría (pp. 8-44). Boston, MA: Houghton Mifflin.

Valdés, G. (2000). Spanish for Native Speakers: AATSP Professional Development Series Handbook for Teachers K-16. New York, NY: Harcourt.

Villa, D. J. (2004). Heritage language speakers and upper-division language instruction: Findings from a Spanish linguistics program. In H. Byrnes \& H. H. Maxim (Eds.), Advanced Foreign Language Learning: A Challenge to College Programs (pp. 88-98). Boston, MA: Heinle.

\section{NOTES}

${ }^{1}$ In all comments, spelling was edited to reflect academic Spanish. Neither grammar not content was edited.

${ }^{2}$ Due to class absences, not all students completed every journal entry.

${ }^{3}$ Diglossia is defined broadly as "the reservation of highly valued segments of a community's linguistic repertoire (which are not the first to be learned, but are learned later and more consciously, usually through formal education), for situations perceived as more formal and guarded; and the reservation of less highly valued segments (which are learned first with little or no conscious effort), of any degree of linguistic relatedness to the higher valued segments, from stylistic differences to separate languages, for situations perceived as more informal and intimate" (Fasold, 1984: 53).

${ }^{4}$ French is only spoken by $1 \%$; less than Spanish, although French is an official language.

5 This student had family outside of Rockford, Illinois. She was referencing what she knew of Rockford, vs., for example, Chicago, with its more substantial Hispanic population.

\section{${ }^{*}$ ACKNOWLEDGEMENTS}

We would like to thank the Faculty Institute on Learning Technologies at St. Mary's University for their support of this project. We also thank the guest editor, Dr. Francisco Salgado-Robles, for this special issue, and the two anonymous reviewers whose comments greatly improved the manuscript. Finally, much gratitude is owed to our students, without whom this manuscript would not exist, and who teach us daily about their lives, experiences, and language use. 